\title{
Influence of Soil Type on Yield and Quality of Different Apple Cultivars
}

\author{
Alina Viorica ILIE ${ }^{1 *}$, Cristina PETRISOR ${ }^{2}$, Dorel HOZA ${ }^{3}$, Viorel Oltenacu ${ }^{1}$ \\ ${ }^{1}$ Research and Development Station for Tree Fruit Growing Baneasa, Blvd. Ion Ionescu de la Brad, \\ No.4, District 1, Bucharest \\ ${ }^{2}$ Research and Development Institute for Plant Protection, Blvd. Ion Ionescu de la Brad , No.8, District 1, \\ Bucharest \\ ${ }^{3}$ University of Agronomic Sciences and Veterinary Medicine, Blvd. Marasti, No.59, District 1, Bucharest \\ *)Corresponding author, e-mail: alisa_ilie@yahoo.com
}

BulletinUASVM Horticulture 74(1) / 2017

Print ISSN 1843-5254, Electronic ISSN 1843-5394

DOI:10.15835/buasvmcn-hort:12638

\begin{abstract}
The adaptive capacity of different fruit tree cultivars to soil types and climatic conditions it is decisive for establishing differences between genotypes regarding to growth, yield and quality and the right choice of varieties for cultivation. The objective of this study was to determine influence of different soil type on apple yield and quality. To investigate the variation in fruit quality, apples were harvested at commercial maturity on two different soil type.

The investigations was conducted in experimental apple orchards located in Focsani region on two different soil type: luvic brown typical and luvic brown pseudogleyic. Fruits of Jonathan and Golden Delicios cultivars were tested for color, soluble solids content, total acidity, ascorbic acid, anthocyanins content and chlorophyls content with specific analytical methods.

At harvest yield, dry matter, soluble solids content, ascorbic acid and acidity were affected by soil type. In this study, no significant soil effect was found on color, anthocyanins and chlorophyll fruit content.

The results obtained in this study suggest that luvic brown pseudogleizate soil leading to increased yields and enhanced fruit quality.
\end{abstract}

Keywords: apple cultivars, brown luvic soil, pigments, soluble solids

\section{INTRODUCTION}

Apple fruits have very high nutritional values making them very helpful to the human body and therefore are cultivated all over the world (Lepaja et al., 2014). Firmness and sugar content are important quality attributes that directly influence consumers on purchasing fresh apple fruit. Also organic acid together with soluble solids and flavor contribute to the overall organoleptic quality of fresh apple fruits (Nour et al., 2010).

Beside the climatic factors the edaphic factors influence growth and fruiting of the tree, the quality and production of fruit (Murtic et al., 2012; Zoppolo et al., 2011). Soil type and properties, fertilizers have influence on development of root system and on crop productivity and aromatic and texture features of fruits (Sanchez et al., 2007). It is well known that soil have an important impact on aromatic characteristic of fruits like grape (Royer et al., 2012). Also, studies of Cudur et al., 2014 demonstrate that soil type influenced grape acidity and production but have insignificant effect on the sugar accumulation.The previous studies of Roger et al., 2004 shows that soil have an hight impact on apple texture. According to Shqahu, (2007), apple can be adapted in different soils; it grows in cool climate, warm and optimum air moisture. Impact of different climatic factors, 
Tab. 1. Soil fertility in orchards with different soil type

\begin{tabular}{cccccccccccccc}
\hline Soil & $\begin{array}{c}\text { Depth } \\
\text { (cm) }\end{array}$ & $\begin{array}{c}\mathrm{Humus} \\
\%\end{array}$ & $\begin{array}{c}\mathrm{NO}_{3}^{-} \\
\%\end{array}$ & $\begin{array}{c}\mathrm{P}_{2} \mathrm{O}_{5} \\
\mathrm{ppm}\end{array}$ & $\begin{array}{c}\mathrm{K}_{2} \mathrm{O} \\
\mathrm{ppm}\end{array}$ & $\begin{array}{c}\mathrm{Fe} \\
\mathrm{ppm}\end{array}$ & $\begin{array}{c}\mathrm{Cu} \\
\mathrm{ppm}\end{array}$ & $\begin{array}{c}\mathrm{Mn} \\
\mathrm{ppm}\end{array}$ & $\begin{array}{c}\mathrm{Zn} \\
\mathrm{ppm}\end{array}$ & $\begin{array}{c}\mathrm{Co} \\
\mathrm{ppm}\end{array}$ & $\begin{array}{c}\mathrm{Ca}^{2+} \\
\text { mequiv./100g }\end{array}$ & $\begin{array}{c}\mathrm{Mg}^{2+} \\
\text { mequiv./100g }\end{array}$ & $\begin{array}{c}\mathrm{pH} \\
\mathrm{H}_{2} \mathrm{O}\end{array}$ \\
\hline $\begin{array}{c}\text { Brown luvic } \\
\text { typical (S1) }\end{array}$ & $0-20$ & 0.67 & 0.070 & 2 & 70 & 1 & 5 & 49 & 1 & 0 & 44 & 26.1 & 5.2 \\
\hline & $20-50$ & 1.52 & 0.123 & 3 & 133 & 6 & 4 & 75 & 1 & 0 & 34.4 & 13.2 & 4.9 \\
\hline $\begin{array}{c}\text { Brown luvic } \\
\text { pseudogleyic } \\
\text { (S2) }\end{array}$ & $0-20$ & 1.89 & 0.116 & 92 & 152 & 10 & 5 & 189 & 2 & 0 & 37 & 16.7 & 4.75 \\
\hline
\end{tabular}

harvest time, cultivar on apple quality was intense studied but little information is available about soil impact on yield and quality of apple. So, it is important that regional growers obtain additional information about attributes and limitations of soil types to identify the most suitable cultivars with high quality of fruits for growing.

The aim of the present study was to compare the effect induced by two different soils (brown luvic typical and brown luvic pseudogleyic) on apple fruit quality.

\section{MATERIALS AND METHODS}

Studied cultivars Golden Delicious and Jonathan have been collected from experimental orchard located at Focsani region. Both cultivars resulted by two different soil: brown luvic typical (S1) and brown luvic pseudogleyic (S2). The soil fertility for each soil type was characterized and it is presented in table 1.

Yield per tree $(\mathrm{kg})$ of each cultivar was measured on five trees on three replications.

A sample of randomly picked 15 fruits per cultivar was harvested at commercial maturity for determining of quality attributes.Fruit quality parameters fresh weight of fruit, total soluble solids (TSS), titratable acidity (TA), ascorbic acid, firmness, color, anthocyanins content, chlorophyll a (chl a), chlorophyll b (chl b) and carotenoids content were immediately assayed after harvest with specific analytical methods.

Total soluble solids concentration (TSS) was assessed in juices of fruits using an thermocompensated Atago hand-refractometer (model PR-101, ATAG0, Japan) expressed as Brix.

Titratable acidity (TA) was determined by titrating of known volume of juice aliqout with 0.1
$\mathrm{N} \mathrm{NaOH}$ to an end point pH 8.1 using a pH Meter (Hanna Instruments, Italy) and the total acidity calculated and expressed as malic acid.

Assessment of ascorbic acid content was achieved by quantitative reduction of 2,6-diclorphenol-indophenol and the excess of dye is spectrophotometrical determined at 500nm.The results were expressed as $\mathrm{mg} / 100 \mathrm{~g}$ fresh weight.

Flesh firmness $\left(\mathrm{kg} / \mathrm{m}^{2}\right)$ was averaged from two measurements taken at the equator of each apple, after removing a peel evaluated with a penetrometer (Model FT 327 ) fitted with a cylindrical $11.1 \mathrm{~mm}$ diameter head.

External color ( $\mathrm{L}^{*}, \mathrm{a}^{*}$, and $\mathrm{b}^{*}$ ) was measured on 10 apples from each group with Hunter Lab colorimeter (Model MiniScan XE Plus). Measurements were conducted in CIE $L^{*} a^{*} b^{*}$ system. $L^{*}$ is a measure of lightness, where values range from completely opaque $(0)$ to completely transparent (100), $a^{*}$ is a measure of redness (or $-a^{*}$ of greenness) and $b^{*}$ of yellowness (or $-b^{*}$ of blueness) on the hue circle. The hue angle, $h^{\circ}$, describes the relative amounts of redness and yellowness where $0^{\circ} / 360^{\circ}$ is defined for red/ magenta, $90^{\circ}$ for yellow, $180^{\circ}$ for green and $270^{\circ}$ for blue colour.

The total anthocyanins content of the fruit was assessed based on $\mathrm{pH}$ differentiation method previously described by Giusti et al., 2002. Results were expressed as mg cyanidin- 3 glucoside $/ 100 \mathrm{~g}$ fresh tissue.

For chlorophyll quantification a known weight of leaves was extracted in acetone 100\% (v/v) and filtered through a Whatman No.1 filter paper. The chlorophyll and carotenoids content was quantified according to Lichtenthaler and Welburn, 1983. Absorbance of the extract was 
Tab. 2. Influence of soil type on the biometrical parameters, firmness and acidity of apple fruit

\begin{tabular}{cccccccc}
\hline Cultivar/soil & $\begin{array}{c}\text { Fruit } \\
\text { weight } \\
(\mathrm{g})\end{array}$ & $\begin{array}{c}\text { Yield per } \\
\text { tree }(\mathrm{kg})\end{array}$ & $\begin{array}{c}\text { Dry } \\
\text { matter } \\
(\mathrm{g} \%)\end{array}$ & $\begin{array}{c}\text { Flesh } \\
\text { firmness } \\
\left(\mathrm{kg} / \mathrm{cm}^{2}\right)\end{array}$ & $\begin{array}{c}\text { Titratable acidity } \\
(\text { malic acid \%) }\end{array}$ & $\begin{array}{c}\text { Soluble } \\
\text { solids } \\
\left({ }^{\circ} \text { Brix }\right)\end{array}$ & $\begin{array}{c}\text { Ascorbic acid } \\
(\mathrm{mg} / 100 \mathrm{mg})\end{array}$ \\
\hline $\begin{array}{c}\text { Jonathan } \\
\text { S 1 }\end{array}$ & 112 & 22 & 13.93 & 7.8 & 0.94 & 12 & 14.04 \\
\hline $\begin{array}{c}\text { Jonathan } \\
\text { S 2 }\end{array}$ & 130 & 29 & 14.45 & 8.9 & 0.76 & 13 & 16.05 \\
\hline $\begin{array}{c}\text { Golden } \\
\text { Delicious } \\
\text { S 1 }\end{array}$ & 129 & 33 & 13.96 & 6.1 & 0.48 & 12.4 & 13.32 \\
\hline $\begin{array}{c}\text { Golden } \\
\text { Delicious } \\
\text { S 2 }\end{array}$ & 215 & 38 & 15.27 & 9.5 & 0.37 & 14.9 & 15.68 \\
\hline
\end{tabular}

determined spectrophotometrically at $662 \mathrm{~nm}$ and $645 \mathrm{~nm}$ and $470 \mathrm{~nm}$. Concentration of chlorophyll $(\mu \mathrm{g} / \mathrm{mL})$ was calculated using Lichtenthaler's equations.

\section{RESULTS AND DISCUSSION}

It can be seen from the results that the acidity is lower at fruits grown on soil S2 and also soluble solids content is higher for this fruits (tab. 2).

According to data from table 2 significant differences between soil type were observed for flesh firmness, weight and dry matter of fruit . At Jonahan cultivar we observed small differences in terms of dry matter and yield between both soil types. Fruits of both cultivars Jonathan and Golden Delicious were larger and firmer on soil S2. These was confirmed by the average fruit weight. This results were similar with those obtained by Rato et al., 2008 who found that fruits of plum were bigger in the Haplic Luvisol soil compared to Vertic Luvisol. This results are consisted with those of Royer et al., who reported that apples coming from orchards from loam and sandy-clay soil were more crunchy and firmer (highest values of hardness) than apples from clay soil. Can be seen from the obtained results that the acidity is lower in fruit growing in the brown luvic pseudogleyic soil (S2) both for Jonathan and for Golden Delicious cultivar.

In brown luvic pseudogleyic soil (S2), fruits of both cultivars presented in general a higher value for soluble solids and dry matter. Findings of Aruani et al., 2011 demonstrated that a high Na percentage was negatively related with pear yield but increase the percentage of soluble solids, titratable acidity and flesh firmness. Experimental data of Fazio et al., 2012 indicated that both the clay soil and the sandy soil showed increases growth of the apple trees. Also, they supported that leaf zinc, sodium, potassium, manganese, calcium, magnesium, and phosphorus concentration showed significant differences between soil types.

Lightness did not show any significant difference with ragards soil type and cultivar. Chromatic parameter $b^{*}$ of fruit is bigger in case of soil S2 type. Chromatic parameter a* of Jonathan fruit have positive value which means that the fruit has a pronounced degree of red, but Golden Delicious have a negative value of $\mathrm{a}^{*}$ parameter which means that this fruit have a green-yelow color. Hue of fruit represented through hue angle $\left(h^{\circ}\right)$ have values between 98-99 that corresponding green-yellow light colour for Golden Delicious cultivar and between 50-70 that evidence a redyellow light colour .

It was observed from spectras shape a peak at $560 \mathrm{~nm}$ for Golden Delicious cultivar and a minimum at $680 \mathrm{~nm}$. The high values of reflectance $55 \%$ are related to higher chlorophyll and carotenoids content specific for this cultivar. However for Jonathan cultivar we observed a maxim at $630 \mathrm{~nm}$ and a minimum at $680 \mathrm{~nm}$. At this cultivar we observed decrease of reflectance value (40\%).

Regarding fruit chlorophyll content data presented in table 3 show that chl a and chl b content was similar for both soil type in case of both cultivars studied. The soil type influence was not significant for the anthocyanins content (tab. 


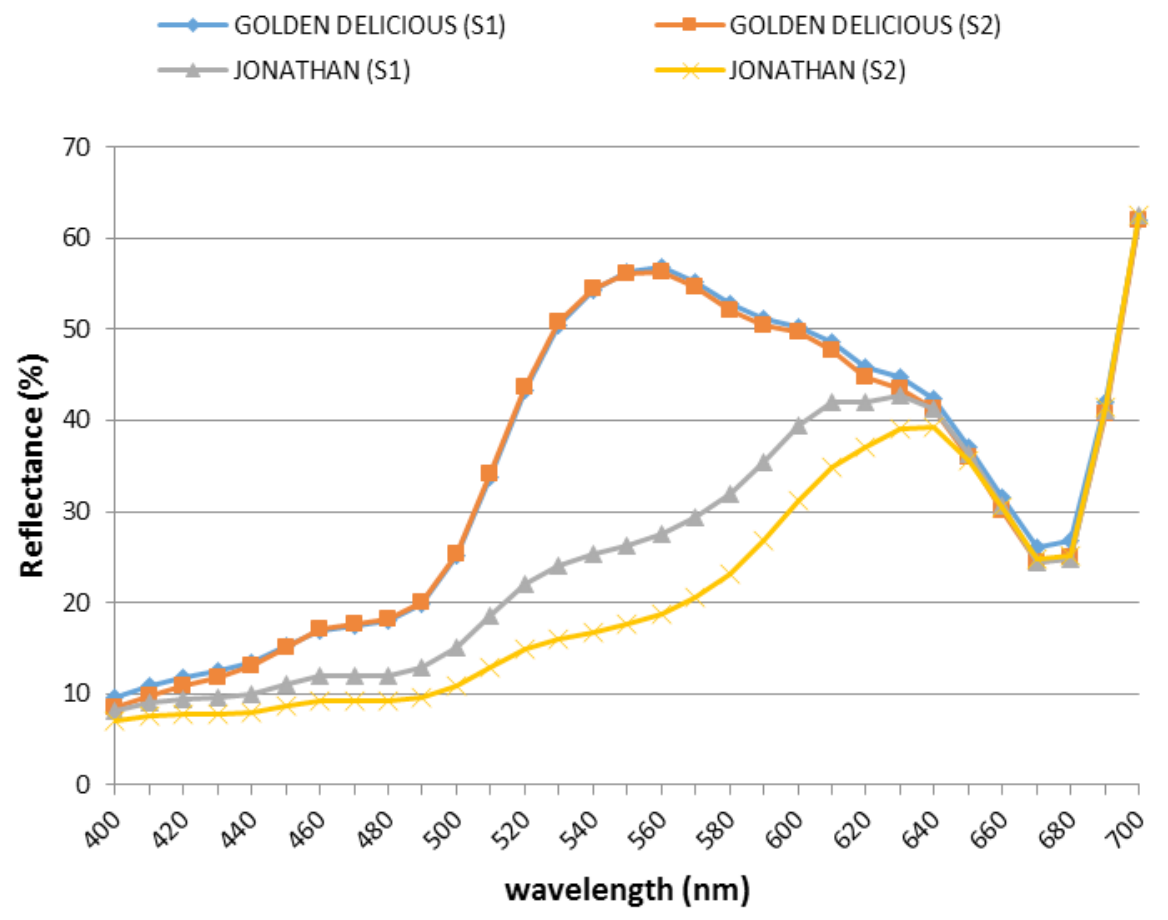

Fig.1. Effect of soil type on reflectance spectra of apple cultivars

Tab. 3. Influence of soil type on the pigments content and color of apple fruits

\begin{tabular}{|c|c|c|c|c|c|c|c|c|c|c|c|}
\hline \multirow{2}{*}{\multicolumn{2}{|c|}{$\begin{array}{cc}\begin{array}{c}\text { Cultivar / Antocyanins } \\
\text { soil }\end{array} \\
\text { (mg\%) }\end{array}$}} & \multirow{2}{*}{$\begin{array}{c}\mathrm{Chl} \mathrm{a} \\
(\mathrm{mg} / \mathrm{l})\end{array}$} & \multirow{2}{*}{$\begin{array}{c}\mathrm{Chl} \mathrm{b} \\
(\mathrm{mg} / \mathrm{l})\end{array}$} & \multirow{2}{*}{ Chl.a/b } & \multirow{2}{*}{$\begin{array}{l}\text { Carotenoids } \\
(\mathrm{mg} / \mathrm{l})\end{array}$} & \multirow{2}{*}{$a+b / x+c$} & \multicolumn{5}{|c|}{ Color parametrs } \\
\hline & & & & & & & $\mathrm{L}^{*}$ & $a^{*}$ & $\mathrm{~b}^{*}$ & $\mathrm{C}^{*}$ & $\mathrm{~h}^{\circ}$ \\
\hline $\begin{array}{l}\text { Jonathan } \\
\text { S } 1\end{array}$ & 12.2 & 0.69 & 0.59 & 1.17 & 0.56 & 2.28 & 52.81 & 17.59 & 28.14 & 33.18 & 57.98 \\
\hline $\begin{array}{l}\text { Jonathan } \\
\text { S } 2\end{array}$ & 12.4 & 0.64 & 0.28 & 2.28 & 0.43 & 2.14 & 58.94 & 11.59 & 33.02 & 35 & 70.65 \\
\hline $\begin{array}{l}\text { Golden } \\
\text { Delicious } \\
\text { S } 1 \\
\end{array}$ & - & 0.5 & 0.21 & 2.38 & 0.32 & 2.18 & 73.31 & -6.75 & 45.83 & 46.32 & 98.37 \\
\hline $\begin{array}{c}\text { Golden } \\
\text { Delicious } \\
\text { S } 2 \\
\end{array}$ & - & 0.64 & 0.17 & 3.76 & 0.34 & 2.38 & 73.16 & -7.77 & 46 & 46.65 & 99.59 \\
\hline
\end{tabular}

3). Also, carotenoids pigments content are small and varies very little between the two types of soil.

Kim et al., 2012 showed that sugar content, color and weight of grapevine cultivars were great influence by soils with hardened layers. Sharples, 1980 showed that physical and chemical properties of soil and climatic factors affect the rate of ripening and qualities of pears grown in South Africa, North America. Sanchez et al., 2007 found that cover crops did affect soil properties and apple yield.

\section{CONCLUSION}

The results obtained in this study suggest that luvic brown pseudogleyic soil have a special favorability for both apple cultivars leading to increased yields and enhanced fruit quality.

Flesh firmness was significantly higher for both cultivars cultivated on brown luvic pseudogleyic soil.

This study also revealed that color and pigments content were not significantly influenced by soil type. 


\section{REFERENCES}

1. Aruani MC, Barnes N, Striebeck G, Orse B, Machuca Y (2011). Physical and physicochemical properties of saline soils and effects on yield and quality of Williams pear in the Uppr Rio Negro Valley, Argentina, Acta Hort. 900:303308.

2. Cudur F, Iliescu M, Comsa M, Popescu D, Cristea C (2014). Soil type influence on yield quantity and quality at grape varieties for white wines obtained in the viticultural centre Blaj. Bulletin USAMV Horticulture 71(1):21-28.

3. Echenique MC, Apcarian A, Reeb P, Aruani MC (2007). Growth-yield relationship of grapevine cultivars on soils with hardened layers, Alto Valle of the Rio Negro, southern wine growing region of Argentina, Agricultura Tecnica 67:261-270.

4. Fazio G, Kviklys D, Grusak MA, Robinson T (2012). Soil pH, soil type, and replant disease affect growth and nutrient absorbtion of apple rootstocks. New York fruit Quarterly 20(1):22-28.

5. Giusti MM, Wrolstad RE (2002). Characterization and measurement of anthocyanins by UV-visible spectroscopy. In: Wrolstad R.E., editor. Current protocols in food analytical chemistry. New York, NY, USA: John Wiley and Sons Inc.: F 1.2.1.-1.2.13.

6. Lepaja K, Kullaj E, Lepaja L, Avdiu V, Krasniqi N, Zajmi R (2014). Fruit quality parameters of three apple cultivars in western Kosovo. $9^{\text {th }}$ International Symposium on Agriculture Dubrovnik, Croatia.

7. Lichtenhaller HK, Wellburn AR (1987). Determinations of total carotenoids and chlorophylls $a$ and $b$ of leaf extracts in different solvents. Biochem. Society Transactions 591592.

8. Kim SH, Park SJ, Han JW, Cho JG, Choi HS, Lim TJ, Yun HK (2012). Relative contribution rate on soil physicochemical properties related to fruit quality of "Hongro” apple.

9. Murtic S, Civic H, Duric M, Paunovic G, Sekularac G, Behmen F, Krsmanovic M (2013). The content of some antioxidants in apple depends on the type of fertilization. Pol. J. Environ. Stud. 22(2):475-480.

10. Nour V, Trandafir I, Ionica ME (2010). Compositional characteristics of fruits of several apples cultivars. Not. Bot. Hort. Agrobot. Cluj 38(3):228-233.

11. Rato AE, Agulheiro AC, Barroso JM, Riquelme F (2008). Soil and rootstock influence on fruit quality of plums. Scientia Horticulturae 118:218-222.

12. Royer G, Madieta E, Reveillère $M$, Symoneaux R, Khaldi S, Jourjon F (2003). Preliminary study of the soil impact on apple texture. 3rd International Symposium on Food Rheology and Structure, Laboratoire Grappe, Ecolesupérieured' Agriculture, BP 748, 49007 Angers cedex 01: 645-646.

13. Sanchez EE, Giayetto A, Cichon L, Fernández D, Aruani MC, Curetti M (2007). Cover crops influence soil properties and tree performance in an organic apple (Malus domestica Borkh) orchard in northern Patagonia Plant Soil 292:193-203.

14. Zoppolo RJ, Stefanelli D, Bird GW, Perry RL (2011). Soil properties under different orchard floor management systtems for organic apple production. Org. Agr. 1:231246. 